\title{
Implementation of restaurant location searching Geographic Information Systems using Android-based local based services method
}

\author{
Raja Nasrul Fuad ${ }^{1 *}$ Hafni $^{2}$, Fadli Pratama ${ }^{3}$ \\ 1,2,3 Universitas Pembangunan Pancabudi, Medan, Indonesia \\ ${ }^{1}$ rajanasrulfuad@dosen.pancabudi.ac.id
}

open

access

*Corresponding Author

Article History:

Submitted: 12 September 2021

Accepted: 12 September 2021

Published: 12 September 2021

Keywords:

Android-based; Geographic

Information System; Restaurant.

Brilliance: Research of

Artificial Intelligence is licensed

under a Creative Commons

Attribution-NonCommercial 4.0

International (CC BY-NC 4.0).

\begin{abstract}
Finding a restaurant location as a place to enjoy food becomes something that is very inconvenient, especially for tourists or food connoisseurs who are not familiar with the area. It takes several tools, especially the use of Android-based smartphones as an operating system that is very popular with the public lately. This research is expected to make it easier for users to find food in restaurants that users want. The use of this system is divided into two, namely admin and user (general users). This system is integrated with the existing GPS on the smartphone. This application also shows the distance traveled and time traveled by motorbike or car to the location and displays an estimate if using public transportation.
\end{abstract}

\section{INTRODUCTION}

The development of technology in the field of information and communication, especially the internet, plays an important role in making it easier for consumers to get culinary information, while also providing culinary entrepreneurs to market their products, as well as developing a wider market. The development of technology is also accompanied by the need for mobility, especially the high use of smartphones. The rapid growth of smartphone use based on the Emarketer report, it is estimated that in 2016 there are two billion active smartphone users worldwide and Indonesia is one of the countries that has the third-largest smartphone growth. Indonesia is also expected to become the fourth-largest smartphone user with around 100 million active smartphone users in 2018. Culinary developments in Indonesia are accompanied by advances in mobile device technology and have increased the mobility of consumer activities so that the need for location and restaurant information emerges quickly and easily. This study aims to develop applications that can assist consumers in finding information on mobile devices that use Location-Based Service (LBS) technology. (Layona \& Yulianto, 2016)

The current technology also makes it easier for programmers to make this application, one of which is LocationBased Service (LBS). Location-Based Service (LBS) or this location-based service is a service that displays information that can be accessed via mobile devices and connected to a network and is able to show the geographical location where the device is located or the location of a place like a case example here to find the nearest restaurant. . Location-Based Service (LBS) will make it easier for users to search remote areas, as well as what information is available at the location obtained by users. (Layona \& Yulianto, 2016)

\section{Formulation of the problem}

Based on the background of the problem above, the formulation of this problem is:

- How to build an application for finding the location of restaurants in the city of Medan using the Location-Based services method?

- $\quad$ How to implement the application on Android-based devices using Location Based Services (LBS)?

\section{Location-Based Services (LBS)}

\section{LITERATURE REVIEW}

Location-Based Services (LBS) is a general term used to describe the technology used to locate the device in use. According to Qusay H. Mahmoud, LBS is a service that is used to find out the position of the user, then uses that information to provide personalized services and applications. The two main elements of LBS are:

\section{Location Manager (API Maps)}

Providing tools/sources for LBS, Application Programming Interface (API) Maps provides facilities for displaying, manipulating maps along with other features such as satellite views, roads, or a combination thereof. This package is located at com.google.android.maps. 


\section{Location Providers (API Locations)}

Users can determine their location, track movement/movement, as well as proximity to a specific location by detecting displacement. (Safaat, 2011)

Broadly speaking, LBS can be divided into two, namely:

1. Pull Service: Service is only provided when there is a request from the user.

2. Push Service: The service is provided directly by the service provider without waiting for a request from the user.

Currently, it is built from new information and communication technologies (New Information and Communication Technologies / NICTS) which include: mobile telecommunications systems and handheld devices, with data originating from the internet and Geographic Information Systems (GIS) using spatial databases. (Nusyirwan, 2009)

Location-Based Services have five important components, which include:

1. Mobile Devices: A tool used by the user to request the required information. Information can be provided in the form of sound, images, and text.

2. Communication Network: a communication network that sends user data and requested information from the mobile terminal to the Service Provider and then sends the requested information back to the user. Communication Network can be a cellular network (GSM, CDMA), Wireless Local Area Network (WLAN), or Wireless Wide Area Network (WWAN).

3. Positioning Component: To process service, the user's position must be known.

4. Service and Application Provider: Service providers offer a wide range of services to users and are responsible for processing the information requested by users.

5. Data and Content Provider: Service providers do not always keep all the required data accessible to the user. For that, data can be requested from data and content providers. (Imaniar, 2011)

\section{Open Street Maps (OSM)}

Along with the development of mapping technology, the tendency towards freedom in mapping geospatial elements is increasingly widespread. The increasingly open access to geospatial information through the internet allows users around the world to better utilize geospatial information.

The trend of the emergence of the private sector, community, and volunteer groups in utilizing new technology to develop initiatives such as OpenStreetMap, Google Maps, Map Action, and so on to complement the existing deficiencies in conventional geospatial information is increasingly being felt by the community. Even in certain situations, they seem to be competitors for conventional geospatial information providers because people have started to switch to accessing geospatial information quickly and for free. (UNCEGGIM, 2012)

OpenStreetMap (OSM) as one of the initiatives that were established in 2004 in the UK by a non-profit organization is increasingly showing its existence in facilitating community-based geospatial information for free to the public. OSM provides geospatial information with various themes, such as transportation infrastructure including roads, railways, rivers, as well as other information such as important places, buildings, natural features, and land use, coastlines, and administrative boundaries. (Anonymous, 2012)

OpenStreetMap is an open-source service for creating, editing, and completing maps for free by its users. OpenStreetMap is a service built to complement the world's geographic database for free. The OSM map can be accessed at http://www.openstreetmap.org/. The database is built by the users themselves, namely by recording points, areas, and tracking routes using a GPS II-13 receiver. This information is then used to create points, areas, and paths into the map. OSM data is free for users for various purposes. Users can copy, modify and redistribute data. There are several map backgrounds on the OSM web that can be used, such as standard OSM maps, road maps, cycling path maps, building maps, maps from Bing images, and so on.

OpenStreetMap (OSM) is a tool for creating and sharing information in the form of maps. Anyone can contribute to OSM, and thousands of people add projects every day. Users draw a map on a computer. The most important thing is that OSM maps are stored on the internet, and anyone can access them for free at any time (Humanitarian OpenStreetMap Team, 2015).

OSM is digital, which makes it very useful to us, and in OSM people also share, which means that everyone benefits others. In this unit, you will learn how to create a digital map. You will learn how to use the OSM platform, and you will make your first changes and additions to maps around the world.

\section{Research Stages}

\section{METHOD}

The following are the stages of the research carried out with the title GIS Implementation of the Android-based nearest restaurant search application using the LBS (Local based service) method as follows: 


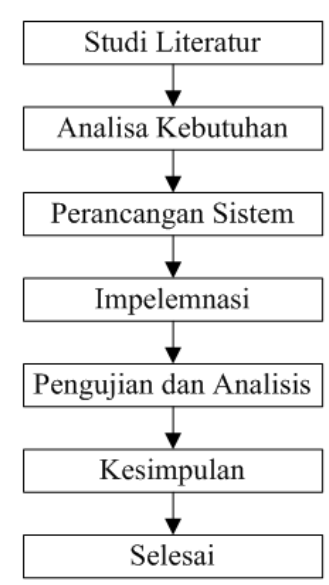

Figure 1, Research Stages

\section{Research design}

\section{UML (Unified Modeling League)}

\section{Use Case}

Describes user interaction in the use of the system shown in the use diagram below.

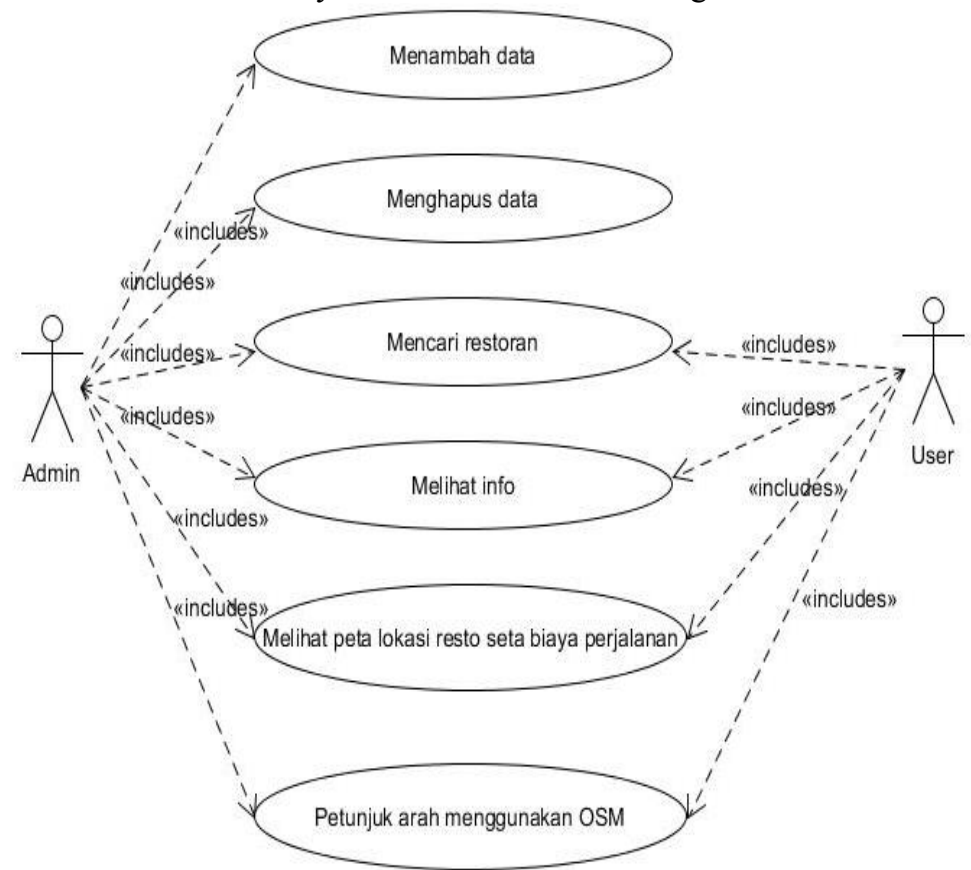

Figure 2. Restaurant Search Application Use Case Diagram

\section{Activity Diagram}

In this application, there are 2 activity diagrams, namely the search activity diagram and the restaurant choice activity diagram. 
Figure 3. Activity Diagram User

It is shown that the user opens the main menu display then selects the main menu in the application's main menu display, then the application requests a list of locations to the server then the server sends data to display a list of restaurants to the user. The user selects the restaurant info in the application then the server sends the location data to be displayed to the user where the location goes to the restaurant.

\section{Activity Diagram Admin}

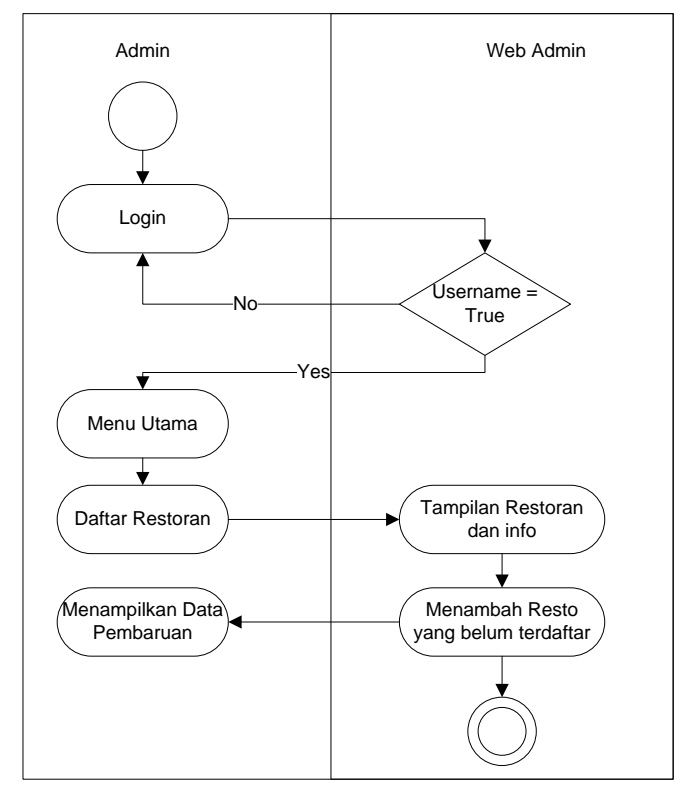

Figure 4. Administrator Activity Diagram

It is shown that the first admin must log in by filling in the username and password, if the username and password are correct, the main menu will appear where the admin can change, modify and delete culinary information data.

\section{Sequence Diagram}

Sequence diagram is a diagram that describes the interaction between each object in each use case in a time sequence. This interaction is in the form of sending a series of data between interacting objects. The square diagram can be seen in the image below 
Figure 5. Restaurant Search Application Sequence Diagram

\section{Implementation System}

\section{RESULT AND DISCUSSIONS}

At the system implementation stage, every application page that has been created in the form of a program file is carried out. The following will explain the steps for the Android-based nearest restaurant search application.

To explain this system, the admin and users must first install the application on their smartphone. If the installation has been done, then you have to choose one of the buttons, whether as a user or admin in order to enter the application.

\section{Admin Application Dashboard}

The main page display is the beginning of the application, including logging into the system that has been created, displaying a location map, creating or adding restaurants that have not been registered in the system manually. How to enter a restaurant by long-pressing a few seconds on the screen and a market will appear, then we add location info and photos of the restaurant.
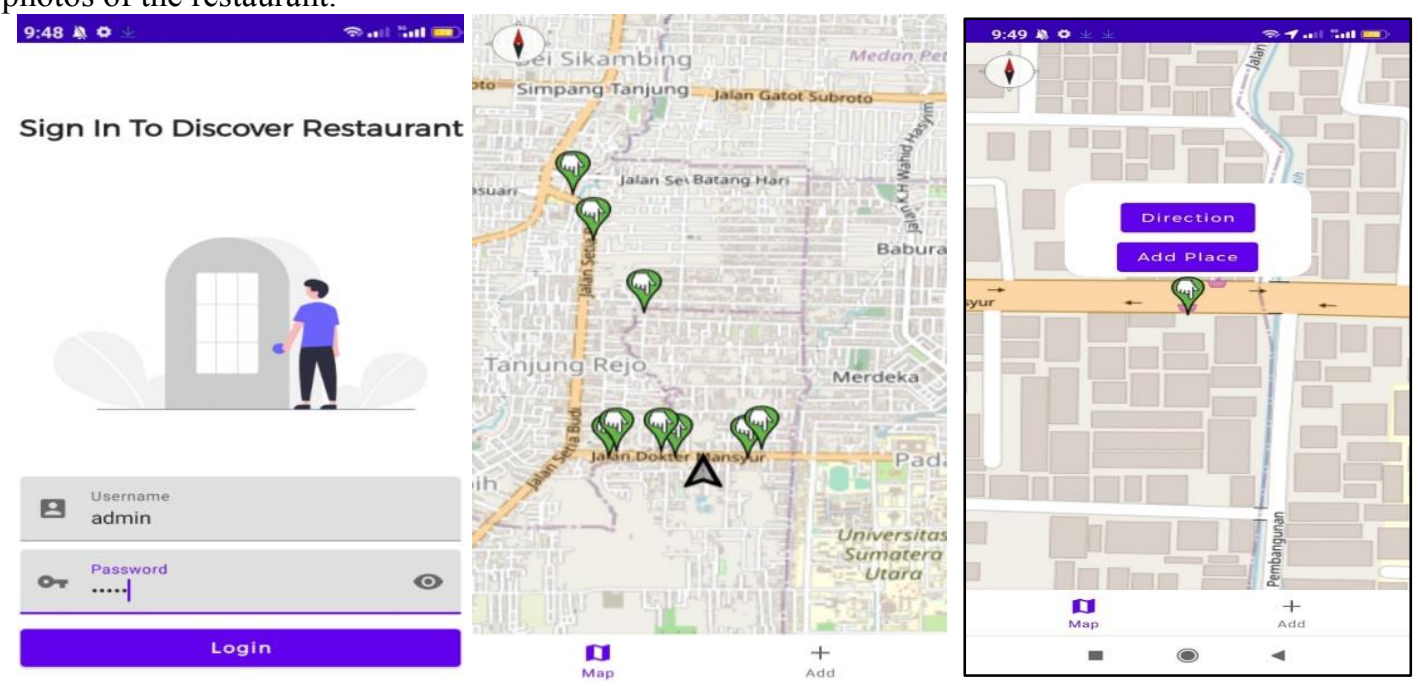


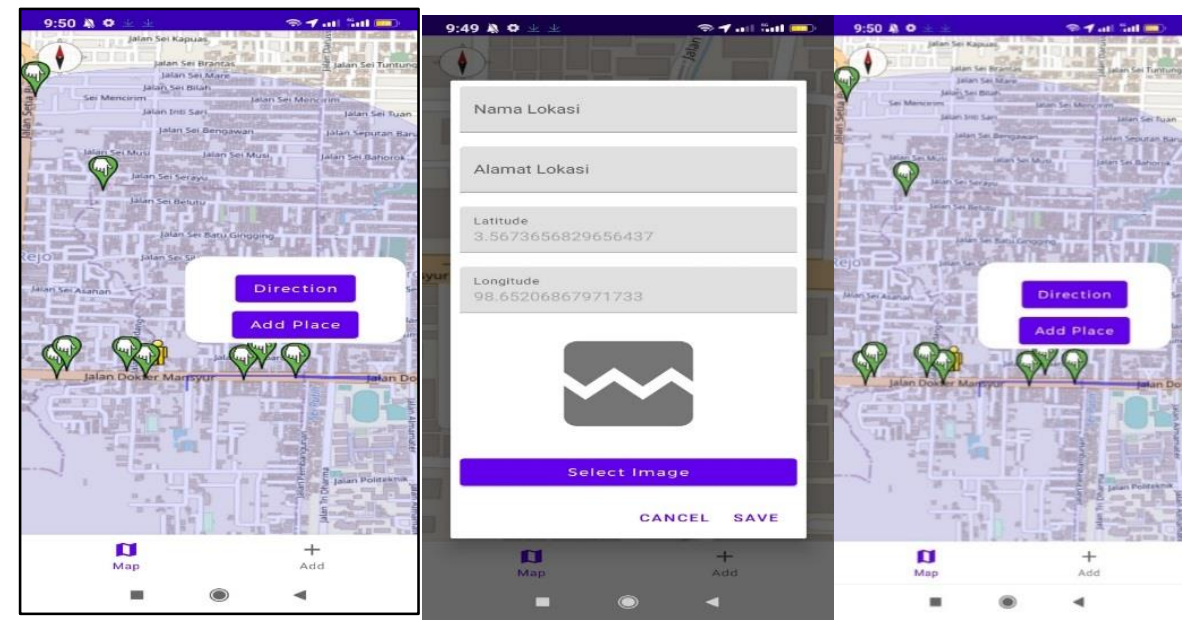

Figure 6. Admin Application Dashboard

\section{User Application dashboard}

The following is the initial view of the user or user in the application. In this display, there are two buttons, namely user and admin. Here the user can directly press the Go Resto! The result obtained is to open the map. Next, the search display will appear, the user will easily determine or choose the restaurant to be visited and easily get location info. This system will also guide the user to get the nearest location. Users can immediately get the closest route to the restaurant. Users will also get information about the selected restaurant along with the distance, travel time and estimated travel costs if using an online motorcycle taxi.
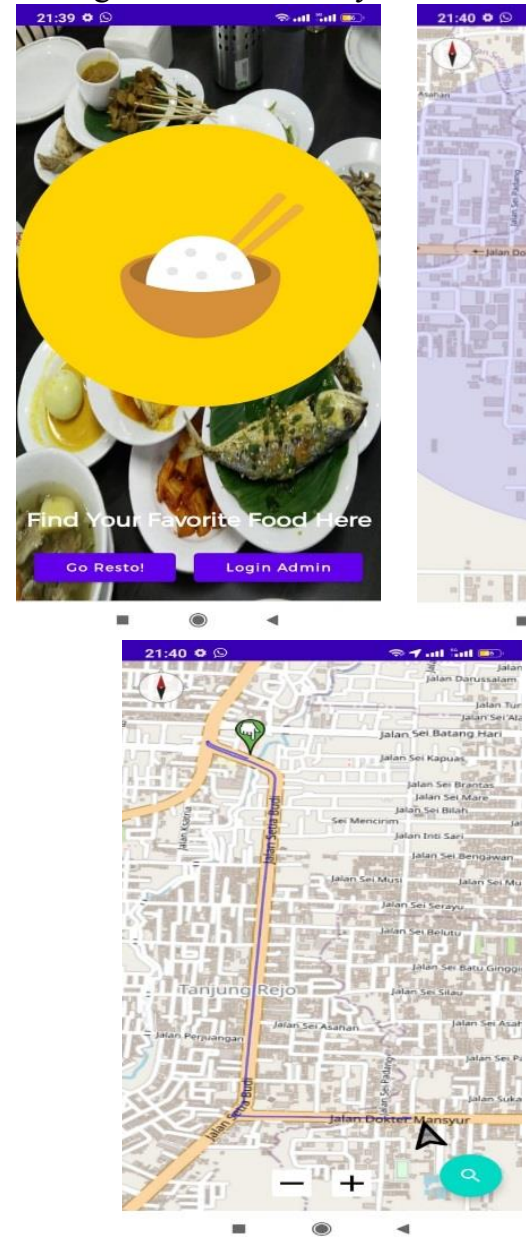
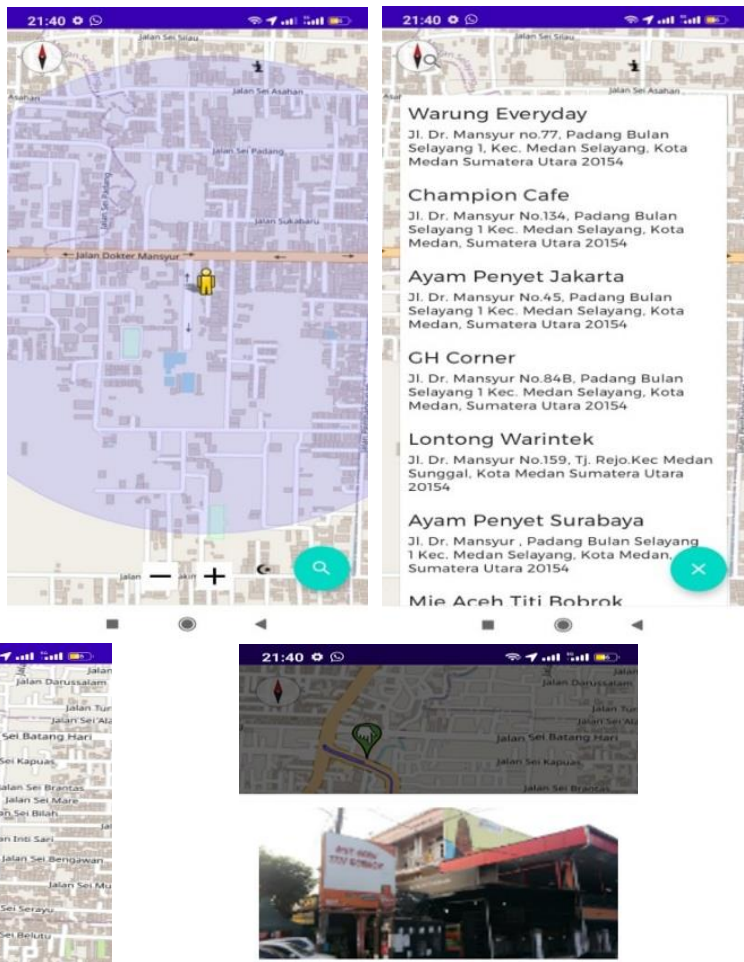

Mie Aceh Titi Bob...

Jl. Setia Budi No.17D, Sei S...

$$
\text { * } \rightarrow \infty
$$

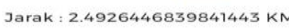

7.5 Menit

Rp. 4800.00

Figure 7. User Application dashboard 
This testing system aims to test the accuracy of the map in the application, which is synchronized from the admin to the user so as to find out whether the application is accurate. The following is a table of test results.

Table 1. Admin Test Results

\begin{tabular}{|l|l|l|l|l|}
\hline No & Test Case & Skenario Uji & Hasil yang Diharapkan & Hasil Uji \\
\hline 1. & $\begin{array}{l}\text { Menekan aplikasi pada } \\
\text { android app }\end{array}$ & $\begin{array}{l}\text { Membuka aplikasi } \\
\text { halaman utama }\end{array}$ & $\begin{array}{l}\text { Menampilkan halaman } \\
\text { utama }\end{array}$ & Berhasil \\
\hline 2. & $\begin{array}{l}\text { Menekan tombol } \\
\text { admin }\end{array}$ & Login & $\begin{array}{l}\text { Menampilkan halaman } \\
\text { peta admin }\end{array}$ & Berhasil \\
\hline 3. & Menekan marker & $\begin{array}{l}\text { Menampilan titik } \\
\text { marker }\end{array}$ & Menampilkan marker & Berhasil \\
\hline 4. & $\begin{array}{l}\text { Menambah lokasi } \\
\text { restoran }\end{array}$ & $\begin{array}{l}\text { Menambah info } \\
\text { restoran }\end{array}$ & $\begin{array}{l}\text { Menampilkan info dan } \\
\text { edit restoran }\end{array}$ & Berhasil \\
\hline 5. & Melihat direction & $\begin{array}{l}\text { Memunculkan } \\
\text { direction }\end{array}$ & Menampilkan direction & Berhasil \\
\hline
\end{tabular}

Table 2. User test result

\begin{tabular}{|c|c|c|c|c|}
\hline No & Test Case & Skenario Uji & Hasil yang Diharapkan & Hasil Uji \\
\hline 1 & $\begin{array}{l}\text { Menekan aplikasi } \\
\text { pada adroid app }\end{array}$ & $\begin{array}{l}\text { Membuka aplikasi } \\
\text { halaman }\end{array}$ & $\begin{array}{l}\text { Menampilkan halaman } \\
\text { utama aplikasi }\end{array}$ & Berhasil \\
\hline 2 & $\begin{array}{l}\text { Tampilan halaman } \\
\text { utama }\end{array}$ & $\begin{array}{ll}\text { Membuka peta } \\
\text { halaman user }\end{array}$ & $\begin{array}{ll}\text { Menampilkan Halaman } \\
\text { utama }\end{array}$ & Berhasil \\
\hline 3 & $\begin{array}{l}\text { Melakukan pencarian } \\
\text { restoran }\end{array}$ & Membuka pencarian & $\begin{array}{ll}\begin{array}{l}\text { Menampilan } \\
\text { pencarian }\end{array} & \text { hasil } \\
\end{array}$ & Berhasil \\
\hline 4. & Memilih restoran & $\begin{array}{l}\text { Membuka info map } \\
\text { resto }\end{array}$ & $\begin{array}{ll}\text { Menampilkan } & \text { peta } \\
\text { direction restoran }\end{array}$ & Berhasil \\
\hline 5. & Melihat info restoran & $\begin{array}{ll}\text { Membuka } & \text { seluruh } \\
\text { info restoran } & \\
\end{array}$ & $\begin{array}{ll}\text { Menampilkan info } \\
\text { restoran }\end{array}$ & Berhasil \\
\hline 6. & $\begin{array}{l}\text { Biaya perjalanan } \\
\text { menggunakan ojol }\end{array}$ & $\begin{array}{l}\text { Membuka info biaya } \\
\text { dan waktu menuju } \\
\text { restoran }\end{array}$ & $\begin{array}{l}\text { Menampilkan hasil jarak, } \\
\text { waktu, dan biaya } \\
\text { perjalana }\end{array}$ & Berhasil \\
\hline
\end{tabular}

\section{System advantages and disadvantages}

The advantages of this system built are:

- This application is open source so that it can be used more freely and can be used by anyone anywhere.

- The appearance of the application is lighter than other applications.

- Can be used when internet connection is not available.

- Can see the location of the narrow road or the fastest road without having to follow the location route.

- Can manually add newly opened restaurants or unregistered restaurants.

- Data in an area can be completed by itself via the OSM editor.

\section{Disadvantages of the system built are:}

- There are still impassable roads but the route lines point towards the marker.

- It is necessary to further develop the use of this map so that it is not limited to only the use of google maps.

- There are no turn directions when getting to the location.

- There is no detailed location info, only showing part of it.

- The function of the OSM data editor is that the quality of the data in OSM is not fully guaranteed because the nature of voluntary participation in building the OSM map causes the responsibility of contributors to the quality of the data to be relatively low.

\section{CONCLUSION}

The conclusions that can be obtained from the implementation of a geographic information system to use a search for the location of a restaurant in the city of Medan with an Android-based local-based service method are:

1. This system can only be used to locate the nearest restaurant using a smartphone as this media application.

2. This system can make it easier for users to find the nearest restaurant, so it is easier for users to determine which restaurant they will visit. 
3. The use of OpenStreetMap maps provides an alternative in GIS development. The route search results show that OpenStreetMap displays the same route as Google Maps for routes with sufficient road data. The difference is that the Google Maps road data that is built is more complete to support the selection of a more diverse route

\section{REFERENCES}

Demers, M.N., 1997, Fundamental of Geographic Information Systems, John Wileys \& Sons, Inc., New York Gistut. 1994. Sistem Informasi Geografis. Gramedia Pustaka Utama

Jogiyanto, J. 2003. Sistem Teknologi Informasi (Pendekatan Terintegrasi: Konsep Dasar, Teknologi, Aplikasi, Pengembangan dan Pengelolaan). Yogyakarta: Andi Yogyakarta.

Layona Rita \& Budi Yulianto, Aplikasi Pencarian Informasi dan Lokasi Tempat Makan Pada Perangkat Mobile Berbasis Android, Jurnal Teknosi, Vol 02 No. 02, Universitas Andalas

Mulyadi, M. (2016). Sistem Informasi Akuntansi. Jakarta: Salemba Empat.

Nusyirwan, N. (2008) “Kajian Proses Pembuatan Gula Merah di Lawang Kabupaten Agam”, Jurnal Teknika, No.28 Vol I THN XVI, Fakultas Teknik Universitas Andalas

Phares, E. J. 1976. Locus of Control in Personality. New Jersey: General Learning Press.

Romney, M. B., \& Steinbart, P. J. (2014). Sistem Informasi Akuntansi. Jakarta: Salemba Empat. Sujarweni, V. W. (2015). Sistem Akuntansi. Yogyakarta: Pustaka Baru Press. Sumarsan, T. (2013). Akuntansi Dasar dan Aplikasi dalam Bisnis Versi IFRS (1ed). Kembangan, Jakarta Barat: Indeks.

Romney, Marshal B \& Steibart, Paul John.(2004). Sistem Informasi Akuntansi. Buku Satu. Edisi Sembilan. Jakarta : Salemba Empat.

Romney, Marshal B \& Steinbart, Paul J. (2006). Accounting Information Sistem (9th ed.), Prentice Hall, New Jersey.

Safaat, N., h. 2012. "Pemrograman Aplikasi Mobile Smartphone dan Tablet PC berbasis android, Cetakan Pertama, Edisi Revisi, Penerbit Informatika Bandung.Bandung

Setiawan, A., 2011, Aplikasi Web Menggunakan Model XML pada Content Website E-Comerce Studio Foto Upside, Jurnal diakses pada Tanggal 11 Desember 2014

Sunyoto, A., 2007. Pemrograman Database dengan Visual Basic dan Microsoft SQL 2000. Yogyakarta: Andi Offset

Sutabri, Tata. 2012. Analisis Sistem Informasi. Yogyakarta: Andi

Wilkinson, Joseph W. Sistem Akunting dan Informasi. Edisi ketiga. Diterjemahkan oleh Agus Maulana. Jakarta. Binarupa aksana, 1993. 